\title{
Gyermekvédelemben érintett gyermekes családok támogatását célzó innovatív modellprogram megalapozása, megvalósítása és értékelő elemzése
}

\author{
Elaboration, implementation and evaluation analysis of an \\ innovative model program to support families with children in the \\ child protection system
}

\section{RÁCZ ANDREA ${ }^{1} \&$ SIK DOROTTYA}

\begin{abstract}
Rácz Andrea: Eötvös Loránd Tudományegyetem, Társadalomtudományi Kar, Szociális Tanulmányok Intézete, Szociális Munka Tanszék (Budapest); racz.andrea.aniko@tatk.elte.hu Andrea Rácz: Eötvös Loránd University, Faculty of Social Sciences, Institute of Social Studies, Department of Social Work (Budapest, Hungary); racz.andrea.aniko@tatk.elte.hu

Sik Dorottya: Eötvös Loránd Tudományegyetem, Társadalomtudományi Kar, Szociális Tanulmányok Intézete, Szociális Munka Tanszék (Budapest); sik.dorottya.borbala@tatk.elte.hu

Dorottya Sik: Eötvös Loránd University, Faculty of Social Sciences, Institute of Social Studies, Department of Social Work (Budapest, Hungary); sik.dorottya.borbala@tatk.elte.hu
\end{abstract}

\begin{abstract}
Absztrakt
Tanulmányunkban egy komplex gyermekjóléti- és gyermekvédelmi szemléletre épülő modellprogramot mutatunk be, mely 2020-2021-ben zajlik, melynek középpontjában a szülőség támogatásán túl a gyermekek szempontjainak, igényeinek a megjelenítése áll több innovatív módszer használata mellett. A modellprogram célja, hogy a családok és gyermekek abban kapjanak segítséget, hogy javuljon a szülői feladatok ellátásának minősége, melyek a családok kapcsolatrendszerére, a szülők gyermekükkel való viszonyára, szükségletkielégítésére is nagy hatással vannak, mind a veszélyeztetett, elhanyagolt gyermekek, mind a szüleiktől külön élő gyermekek és fiatalok esetében. Tanulmányunkban bemutatásra kerülnek a legfontosabb programelemek és az innovációk értékelésének alapját képező komplex módszertanra épülö, kvalitatív és kvantitatív módszertani elemek. Kitérünk arra is, hogy milyen szakmai képzéseket generált a program a megvalósítók számára a megvalósítás folyamatában, és ezek a tudások a későbbiekben hogyan tervezhetők és terjeszthetők a gyermekvédelem praxisában.
\end{abstract}

Kulcsszavak: komplex gyermekvédelmi program, szülőség támogatása, gyermekek aktív részvétele, komplex módszertanú értékelő kutatás, képzésfejlesztés

\footnotetext{
${ }^{1}$ A program a Rubeus Egyesület keretében valósul meg. Rácz Andrea részt vesz a projekthez tematikusan kapcsolódó Szolidaritás a késö modernitásban c. OTKA-kutatásban (FK 129138, 2018-2020, Sik Domonkos), a Menekülés az államtól: privatizáció, exit-stratégiák és alternatív szolgáltatások a gyereknevelésben c. OTKAkutatásban (FK 135215, 2020-2023, Berényi Eszter), valamint a COST Action 19106-Multi-Sectoral Responses to Child Abuse and Neglect in Europe: Incidence and Trends c. projektben az ELTE TáTK Szociális Munka Tanszék képviseletében.
} 
Rácz A. \& Sik D.: Gyermekvédelemben érintett gyermekes családok...

\begin{abstract}
In this article, a complex child welfare and child protection model program (conducted between 2020-2021) is analysed. The focus of this innovative model program is supporting parenting skills and responding more to children's needs. The goal of this program is to improve parenting capability and family relationships by fostering mutual understanding between parents and children so that parents could adequately respond to their children's needs. This is how the program addresses the problems of neglected and maltreated children living with their families, and the problems of children and young adults living in the Hungarian foster care system. Core elements and innovative aspects of the programme are presented. Quantitative and qualitative methods used in the evaluation are also outlined. Based on the outcomes of the model program new forms of vocational trainings and further educational programs can be designed to decrease the harm caused by neglect and maltreatment of children in Hungary, and new methods and services provided by the Hungarian child welfare and protection system can be introduced.
\end{abstract}

Keywords: complex child protection program, supporting parenting skills, active participation of children, complex evaluation research, vocational training development

\title{
Gyermekvédelem-prevenció-innováció
}

A gyermekek védelméröl és a gyámügyi igazgatásról szóló 1997. évi XXXI. törvény megjelenése óta alapvető és visszatérő kérdése a gyermekvédelemnek, hogy mi legyen a gyermekvédelem fókuszában. A magas esetszám, nagy arányú fluktuáció és a megfelelő szakmai háttér hiánya miatt a tüzoltás, a veszélyeztetés azonnali megszüntetése volt az ellátórendszer fókuszában, nem maradt energia, idő és tér a prevenciós szemlélet alkalmazására (Rácz \& Sik, 2020; Sik, 2020). A módszertani eszközök szükössége és a komplex családi helyzetek kilátástalansága, mozdulatlansága miatt a gyermekvédelmi rendszer nem tud érdemben változást generálni a fennálló társadalmi problémák és egyenlötlenségek csökkentésében, illetve a mobilitási csatornák kiszélesítésében (Rácz és mtsai., 2020; Rácz \& Sik, 2020).

A XXI. század gyorsan változó körülményei, a technikai fejlődés és globalizáció számos új kihívással fenyegeti a szociális ellátórendszert és a gyermekvédelmet (Dominelli, 2001). A preventív szemlélet mellett a társadalompolitikai rendszereknek, különös tekintettel a gyermekek fejlesztését, nevelését és védelmét biztosító gyermekvédelmi rendszernek ezekre a változásokra gyorsan, hatékonyan és innovatívan kell reagálnia. A gyermeki szükségletek több szempontból változtak meg az utóbbi évtizedekben, más technikai eszközöket használnak, más módon kommunikálnak a fiatalok, így más módon lehet őket elérni. A gyermekvédelemben fontos és szükséges olyan új módszereknek az alkalmazása, amelyek ezt a folyamatot ösztönzik, és képesek figyelembe venni és megszólítani a gyermekvédelem elsődleges célcsoportját, magukat a gyermekeket és fiatalokat. A szociális munkának mindig is a változás, változtatás, képessé tevés, empowerment állt a középpontjában. A prevenciós megoldások, a társadalmi tervezés, a széles körü társadalmi innovációk hozzájárulnak a társadalmi integrációhoz (Blazer és mtsai., 2017).

A tanulmányban bemutatott modellprogram olyan innovatív programokat, programelemeket épít be a gyermekvédelemi ellátórendszerbe, ahol az innováció és a prevenció egyszerre tud megvalósulni az érintettek társadalmi befogadásának előmozdítása érdekében. 


\section{Családi egyensúly támogatása - a modellprogram bemutatása}

A modellprogram 2020-2121-ben több helyen zajlik, ${ }^{2}$ immár 4. körben. A bevont intézmények között megyei gyermekvédelmi intézmény, vidéki és budapesti gyermekjóléti központ és egy speciális gyermekvédelmi funkciókkal rendelkező kollégium is megtalálható. A négy helyszínen túl két civil szervezet nyújt komplex mentálhigiénés támogatást.

Ebben a tanulmányban célunk bemutatni azokat a programelemeket, innovációkat, amelyek a gyermekvédelem különböző szintjein olyan új módszerek lehetnek, amelyek csökkentik a gyermekjóléti- és védelmi ellátórendszerben dolgozók eszköztelenségét, kiégését, pályaelhagyását, és javítják a kliensekkel való munka hatékonyságát, illetve eredményességét.

Kiemelt témakörök a programban: ${ }^{3} 1$ ) kapcsolati problémákkal küzdő, válófélben lévő vagy elvált szülők és gyermekek támogatása; 2) pszichoszociális fogyatékossággal és szenvedélybetegséggel küzdő szülők és gyermekek támogatása; 3) közösségfejlesztés; 4) családterápiás, mentálhigiénés komplex segítségnyújtás; 5) kiemelés megelőzése és a sikeres hazagondozás komplex támogatása; 6) a gyermekvédelem társadalmi láthatóságának növelése. $^{4}$

A legfontosabb programelemek bemutatását követően ismertetésre kerülnek az innovációk értékelésének alapját képező komplex módszertanra épülő, kvalitatív és kvantitatív módszertani elemek. Kitérünk arra is, hogy milyen szakmai képzéseket generált a program a megvalósítók számára a megvalósítás folyamatában, és ezek a tudások a későbbiekben hogyan tervezhetők és terjeszthetők a gyermekvédelem praxisában. A modellhelyszíneket egy fö szakmai mentor segíti a teljes program ideje alatt, akivel szakmai kérdések, esetleges elakadások esetén konzultálni tudnak.

\section{Fontosabb programelemek a családi egyensúly támogatása érdekében}

A programok helyszínektől függően és az egyes intézményi szükségletek mentén változnak, itt most egy átfogó képet nyújtunk a modellprogramba bekerült programokról, kiemelve egy-egy olyan innovatív elemet, amely jól mutatja be a modellprogram céljait, fő fókuszait.

\section{Válásban érintett családok segítése}

A válás problematikája, a kapcsolattartás körüli konfliktusok a gyermekjóléti alapellátással és gyermekvédelmi szakellátással érintett családok esetében fontos szerepet töltenek be. A válási krízisek támogatására és a konfliktusok megelőzésére, illetve feloldására szükséges új, innovatív módszerek bevezetése a gyermekvédelmi munkába. A válásban érintettek segítése az alábbi módszerekkel történik: apacsoport, egyszülős (anya)csoport, gyermekeknek szervezett müvészetterápiás csoport, ahol a válás során kialakuló érzelmi nehézségek, problémák átbeszélése, feldolgozása a csoportok célja. A különélő szülőpárok számára mediációs

\footnotetext{
${ }^{2}$ http://rubeus.hu/projektek/csaladi-egyensuly-tamogatasa-a-gyermekvedelemben

3 A főbb programelemek az egyes modellhelyszíni programok szakmai dokumentációja alapján kerülnek bemutatásra.

${ }^{4}$ Az egyes programelemekhez szükséges megjegyezni, hogy a közösségfejlesztés és a komplex mentálhigiénés támogatás minden partner programjában szerepel. A gyermekvédelem láthatósága programelem egy videókampány keretében valósul meg, ahol szakellátott gyermekek és fiatalok mutatják be életük kihívásait, azt, hogy milyen témák foglalkoztatják őket a felnőtté válás küszöbén. Fontos célja ennek a társadalom szemléletének is a formálása, hogy ezen célcsoporttal kapcsolatos elöítéletek lebontódjanak.
} 
szolgáltatás biztosítása is fontos célkitüzés, a szülöi feladatok és szerepek kialakítása a különélés során, úgy, hogy a gyermekek érdekeit tartsák szem elött a családtagok.

$\mathrm{Az}$ online tér előtérbe kerülése hívta életre a váláslabirintus ötletét a fövárosi gyermekjóléti partnerintézményben. A váláslabirintus egy online szerepjáték, melyben a különköltözö, válófélben lévő szülőpár nehézségein vezetik végig a játékosokat. A játék lényege a döntési helyzetek tudatosítása és felismerése, a meghozott döntések lehetséges következményeinek előrevetítése.

\section{Gyermekvédelmi szakellátás határán, illetve szakellátásban élők támogatása}

A program célja a gyermekvédelmi szakellátásban nevelkedő gyermekek és szüleik, valamint fiatalkorú anyák és gyermekeik részére támogatás nyújtása, amelynek célja, hogy az önállóságra nevelés támogatásával, a nem adaptív problémamegoldási sémák tudatosításával és lehetőség szerinti korrekciójával elősegítsék a családok átmeneti otthonában elhelyezett, a gyermekvédelmi szakellátásban érintett családok, a gyermekvédelemben élő gyermekek és szüleik sikeres társadalmi integrációját.

A program során a tervezési team megerösítésével a gyermekvédelmi szakellátás alapvető célja, azaz, hogy a gyermek minél hamarabb visszatérhessen a vér szerinti családjába, kerül a fókuszba. Ezeknek a teambeszélgetéseknek fontos eleme, hogy ezeken a gyermek és családja ügyében érintett szakemberek és az érintett család is jelen legyenek. A bevont családok és a szakemberek rendszeresen találkoznak abból a célból, hogy megtervezésre kerüljön a gyermek vér szerinti családjába visszavezető útja, amelyet aztán folyamatosan nyomon lehet követni, és ezáltal gyorsan és hatékonyan lehet reflektálni a felmerülő szükségletekre.

\section{Pszichoterápiás segítségnyújtás a szakellátott gyermekek és fiatalok számára}

A szakellátásban nevelkedő gyermekek és fiatalok részére elengedhetetlen a múltjukból hozott traumák feldolgozásán túl, hogy olyan problémamegoldási eszközökkel rendelkezzenek, amelyek megkönnyítik majd a családjukba történő visszailleszkedést, szélesebben értelmezve pedig a társadalmi integrációt, mindezt önállóságuk támogatásával, hatékony coping mechanizmusok elsajátításával, életvezetésük megtámogatásával. Ennek eszköze a csoportmunka szakellátottak számára.

\section{Pszichoszociális akadályozottság és szenvedélybetegség}

A modellprogram részeként a pszichoszociális akadályozottsággal élő és/vagy szenvedélybetegséggel küzdő szülők segítése is kiemelt feladat a sikeres gyermeknevelés elősegítése terén, másrészt a tinédzserkorú fiatalok támogatása az asszertív kommunikáció elsajátításában. A pszichoszociális akadályozottsággal és/vagy mentális zavarral élő személyek különösen sérülékeny klienscsoportba tartoznak. A segítő tevékenység célja ebben a helyzetben, hogy a mentális zavarral és/vagy addikcióval élő személyeket hozzásegítsék a szakemberek a stressz megfelelő kezeléséhez. Ezen cél elérését szolgálja az asszertív kommunikációs tréning szülőknek: az asszertív viselkedés elősegítése, a kommunikációs készségek fejlesztése, a pozitív érzések kifejezése, a pozitív szemléletű kérések elsajátítása, a negatív, kellemetlen érzések kifejezése, konfliktuskezelési technikák tanulása és a problémamegoldókészség fejlesztése. Emellett kifejlesztésre kerül az ún. Asszerteen mobilapplikáció, mely tinédzsereknek szól, és az erőszakmentes kommunikáció gyakorlásában és készségszintű elsajátításában nyújt segítséget. 


\section{Módszertani, szupervíziós és mentorációs keretek}

A modellprogram komplexitását és innovatív jellegét a benne lévő egyes programelemeken túl a program egészének módszertani és szupervíziós, ${ }^{5}$ illetve mentorációs kerete adja. A gyermekvédelem különböző területein megtapasztalható kiégés, fásultság és eszköztelenség általában, de ebben a krízishelyzetben, amelyben most élünk a járványügyi helyzet miatt, különösen nehéz a benne dolgozók számára. A programban való részvétel, a közös gondolkodás teameken belül és azok között, a programok nyújtotta lehetöségek, az új módszertani eszközök és általában azok fejlesztésébe való bekapcsolódás, az információ széles körü átadása, a módszertani megújulás komoly támaszt nyújt a terepen dolgozóknak.

\section{A modellprogram nyomon követése kutatási eszközökkel}

A modellprogramokban részt vevő családokban a szülöi kompetencia és a gyermeki reziliencia mérésével vizsgáljuk a programok eredményességét, melyet a program elején és végén töltenek ki. Minden adatlap ehhez a programhoz és a megfogalmazott célokhoz illeszkedik, így a szenvedélybetegség, válás, családi konfliktusok kiemelt témakörei a mérőeszköznek. A négy helyszínen összesen minimum 100 család és 200 gyermek esetében történik két alkalommal adatfelvétel (helyszínenként minimum 25/50 kérdőív két alkalommal).

Ezzel párhuzamosan félig strukturált interjúkat készítettünk a célcsoporti tagokkal és a szakemberekkel a tapasztalatok mélyebb megismerése érdekében a program elején és végén, (helyszínenként minimum 4 interjú / alkalom). Ebben az elvárásokat, az egyes programelemek céljait, alkalmazott módszereit, valamint a programelemekkel kapcsolatos vélekedéseket járjuk körbe az elsődleges és másodlagos célcsoport megszólítása által. Fontosnak tartjuk, hogy a szakemberek programról és annak előrehaladásáról való véleményén túl a bevont családok felnőtt tagjai és maguk a gyermekek és fiatalok is véleményt tudjanak nyilvánítani, hogy az adott programelem miben segít nekik, hogyan érzik a gyermekvédelmi munka célelérését saját élethelyzetükben. Ennek egyik központi dimenziója, hogy a járványügyi helyzet milyen segítési formákat és új gyermekvédelmi problémákat hívott életre.

Valamint két alkalommal egységes szempontok mentén zajló helyszini látogatás is történik egy-egy programelem mélyebb megismerése érdekében a négy helyszínen. Ennek célja, hogy dokumentáljuk, hol és kik körében, milyen célok mentén zajlik egy-egy program, milyen módszereket alkalmaznak a szakemberek, és milyen az összbenyomás egy-egy programról (pl. váláslabirintus tervezése, mediációs munkacsoport szakmai megbeszélése).

Elégedettségi kérdölvet is kitöltetünk összesen minimum 100 klienssel a program végén, olyan szülőkkel, akik különböző programelemekben vettek részt. Ennek célja, hogy a teljes programra, a megvalósulás időbeliségére, helyszínére, az alkalmazott módszerekre ránézzünk, és a résztvevőknek legyen lehetősége további témák megfogalmazására, hogy milyen támogatási formákra lenne szükségük gyermekvédelmi problémáik megoldásában. Ez egy lehetséges következő program tervezésének is az alapja. Mind az elégettségi kérdőív, mind a két körös interjú a kliensek esetében kitér arra is, hogy a szakemberek hozzáállását, szakértelmét, szakmai munkáját hogyan értékelik

\footnotetext{
${ }^{5}$ A szupervízió, teammunka, esetmegbeszélések minden szakmai szervezetben vállalt elemek, melynek hiányát vagy rendszertelenségét magukon érzik a szakemberek. A programban a szakmai háttértámogatás nem csak az új feladatok értékelése, de a hatékony munkavégzés keretrendszerének hosszabb távú kialakítása és megszilárdítása szempontjából is kiemelten fontos.
} 
A komplex módszertanra épülő kutatás célja tehát, hogy képet kapjunk arról, hogy egy 7 hónapos program milyen rövidtávú hatást tud nyújtani, hogyan tudja segíteni a családok helyzetét, hogyan tudja fejleszteni, megerősíteni a szülöi kompetenciákat és általában a szülőgyermek kapcsolatot. Vizsgáljuk azt is, hogy mit ad egy ilyen komplex szemléletü program a szakembereknek, a szakmai identitások erősítését és a rendelkezésre álló szakmai módszertani eszköztárat hogyan képes bővíteni. Elemezzük azt is, hogy mindezen új eszközök hogyan építhetők be az adott intézmény életébe.

Mivel a programhelyszínek dokumentálják az elörehaladást, az új eszközök, módszerek átadhatósága is fontos kívánalom a teljes gyermekjóléti- és védelmi terület fejlesztése szempontjából. ${ }^{6}$

\section{Képzési innovációk}

A következőkben olyan képzési innovációkat ismertetünk röviden, melyek a modellprogram megvalósítása során merültek fel igényként. Egyik képzési csomag három témában azoknak a szakembereknek szól, akik a négy helyszínen és a két komplex mentálhigiénés támogatást nyújtó civil szervezet keretében dolgoznak a programokban, a másik pedig szerhasználó apáknak kísérleti jelleggel tapasztalati szakértő bevonásával, mely teljesen újnak számít a gyermekjóléti területi munkában. Mindegyik képzés olyan témát hozott be, melyről a gyermekvédelmi szakemberek előzetes álláspontja szerint igen kevés tudással rendelkeznek. Megfogalmazódott az is, hogy fel se tudják hozni a témát, nem csak a segítő rendszerek hiánya vagy korlátozottsága okán az adott település és kistérség vonatkozásában, de amiatt is, hogy a szenzitív témák megnyitásához, mint a szülő szerhasználata vagy mentális zavara, sem eszközük, sem nyelvük nincsen, azaz, bizonytalanság övezi, hogy hogyan hozzák szóba, mit kezdjenek vele, hova továbbítsák a klienseket.

\section{$3 x 4$ órás tréning a szakemberek részére}

A program részeként a fókuszban lévő területekkel kapcsolatban három tréning és emellett egyéni konzultáció segíti a programban résztvevő emberek munkáját. A trénerek a téma szakértői, a négy órás képzést ehhez a modellprogramhoz fejlesztették célzottan.

A pszichoszociális akadályozottsággal élők támogatása a családban témában a pszichoszociális akadályozottsággal élő személyek ellátását szolgáló szociális és egészségügyi szolgáltatásokat, különösen a közösségi és a nappali ellátásokat járták körbe a résztvevők. A pszichoszociális rehabilitációs alapismeretek és az önsegítés szerepe a felépülés útján volt a tréning fókuszában. Ezen a tréningem egy tapasztalati szakértő vendég segítette a téma mélyebb megismerését.

A második téma az addiktológiai problémákkal küzdök segitése volt. A szenvedélybetegek korai kezelésbe vételének segítése terén módszerek, technikák mellett a viselkedésváltozás elmélete, akadályai és a segítő feladatai az egyes szakaszokban, illetve az addiktológiai ellátórendszer intézményei és szolgáltatásai kerültek átbeszélésre. A beavatkozás technikái, kommunikáció vonatkozásában a szürés, állapotfelmérés, motivációs interjú és a rövid intervenciós technikák, relapszusprevenció volt a tréning fókuszában.

\footnotetext{
${ }^{6}$ A korábbi mérési eredményeket és a teljes szakmai dokumentációt lád bővebben: Rubeus Egyesület, 2018, 2019, 2020.
} 
A harmadik téma a válás és a válással kapcsolatos rendszerszemléletü konzultáció volt. A tréning célja a rendszerszemléletü családterápia, családi konzultáció módszerének alkalmazása volt a gyakorlatban. A négy órás tréning alatt konkrét esetek mentén a rendszerszintű családi konzultáció mint módszer végiggondolása, közös átbeszélése és gyakorlása volt a középpontban.

A képzések alapján a terepen dolgozó szakembereknek nagyon nagy szükségük van minden olyan fórumra és lehetőségre, ahol ventilálhatnak, eseteket közösen elemezhetnek és új módszerekkel ismerkedhetnek meg.

\section{Apa(ra)-apacsoport}

A program részeként kialakításra került egy hely, ahol egymás közt megbeszélhetik azokat a témákat és/vagy kérdéseket a szerhasználattal küzdő apák, amelyek az apasággal kapcsolatosan felmerülnek bennük a mindennapokban. Középpontban a velük szemben támasztott és bennük megfogalmazódott elvárások állnak, valamint az elvárásokkal kapcsolatos nehézségeik és a lehetséges megoldási módok, egymást ösztönözve. A csoport vezetője egy tapasztalati szakértő, aki jelenleg szociális munkát tanul. Az apacsoport öt alkalmas és online formában valósul meg. Ennek előnye, hogy a különböző gyermekvédelmi problémákkal érintett, más-más szervezethez tartozó apák is kapcsolódhatnak, így a fővárosban, illetve vidéken élő apák is a saját problémáik megvitatására részt tudnak venni. Minden apa gyermekvédelmi beavatkozásban érintett, tehát vagy védelembe vett a gyermeke, vagy olyan gyermekvédelmi intézményben nevelkedik hétköznap, ahol a nevelésbe vétel megelőzése a tét.

A tapasztalati szakértővel való munka mindenképpen új iránya a gyermekvédelmi munkának, ebben a projektben egy kísérlet történt ennek megnyitására, de nagyon sok tématerület mentén fontos lenne a tapasztalati szakértők becsatornázása.

\section{Összegzés}

A gyermekvédelmi modellprogram 4+2 helyszínen zajlik jelenleg. A modellprogram célja, hogy a családok és gyermekek abban kapjanak segítséget, hogy javuljon a szülői feladatok ellátásának minősége, melyek a családok kapcsolatrendszerére, a szülők gyermekükkel való viszonyára, szükségletkielégítésére is nagy hatással vannak, mind a veszélyeztetett, elhanyagolt gyermekek, mind a szüleiktől külön élő gyermekek és fiatalok esetében.

A tervezésben a helyi szolgáltatók lettek megszólítva, akik több elemből álló programot dolgoznak ki, majd próbálnak ki a saját gyakorlatukban. Az egyes innovatív elemek kidolgozásába bekapcsolódnak a célcsoporti tagok is, pl. az Asszerteen applikáció fejlesztésébe a tinédzserek. A teljes modellprogram hatékonyságát kvantitatív és kvalitatív kutatási módszerekkel mérjük, melyek speciálisan ehhez a programhoz fejlesztődtek. Jelenleg a programok megvalósítása zajlik, ezzel párhuzamosan pedig a kutatás lebonyolítása.

Az új programelemek gyermekvédelembe való beillesztése jelentős szemléletváltozást képes eredményezni, mind a gyermekekkel végzett segítői munka, mind a szülők megsegítése, szülöi kompetenciáinak fejlesztése által. Ahogy a korábbi eredmények is mutatták, nagyon hamar pozitív irányú változások érhetőek el komplex programokkal, még ha azok pár hónapos időintervallumban müködnek is csak (Rácz, 2018, 2019, 2020).

Az előzetes tapasztalatok azt mutatják, hogy a helyi gyakorlat innovációkkal való megtámogatása mind a kliensek, mind a szakemberek számára megerősítőleg hat. Az innovációk újabb és újabb jó gyakorlatokat képesek kimunkálni és hosszabb távon beépíteni a 
Rácz A. \& Sik D.: Gyermekvédelemben érintett gyermekes családok...

gyermekjóléti és gyermekvédelmi területi munkába, melyre a szakterületnek igen nagy szüksége van. Mindez nem csak a kliensek komplex problémáinak megoldásához járul hozzá, de a szakembereknek is sikerélményt képes nyújtani, ezzel egyidejűleg csökkenti a napi munka során fellépő frusztrációt, kiégettséget.

A program menet közben történő értékelése kevert módszertannal pedig nem csak az előrehaladást, de egy későbbi program tervezését is nagyban segíti, az eredmények a szakmai teamekre, kutatókra is ösztönzőleg hatnak, és inspirációt nyújtanak a módszertani munka folyamatos megújítására, a felmerülő hiányokra való adekvát szakmai válaszok kidolgozására.

\section{Irodalom}

Parpan-Blaser, A. \& Hüttemann, M. (2017). Social Innovation in Social Work. In J. Howaldt, C. Kaletka, A. Schröder \& M. Zirngiebl (Eds.), Atlas of social innovation: 2nd Volume - A world of new practices (pp. 80-83). Atlas of Social Innovation. https://www.socialinnovationatlas.net/fileadmin/PDF/volume-2/01_SILandscape_Global_Trends/01_17_SI-in-Social-Work_Parpan-Blaser-Huettemann.pdf

Dominelli, L. (2001). Globalizáció, jelenkori kihívások és a szociális munka gyakorlata. In Bányai E. (szerk.), A globalizáció kihívásai: Új irányzatok a szociális munkában és a szociális munka szuperviziójában: Szöveggyüjtemény (pp. 6-19). ELTE TáTK. https://www.tatk.elte.hu/dstore/document/1534/Banyai_A_globalizacio_kihivasai.pdf

Rácz, A. \& Sik, D. (2020). Gyermekes családok és a velük dolgozó szociális szakemberek percepciója a családok jól-létét, társadalmi mobilitását előmozdító szolgáltatásokról. METSZETEK, 9(2), 328. https://doi.org/10.18392/metsz/2020/2/1

Rácz, A. (szerk.) (2018). Szülői kompetenciafejlesztést célzó modellprogramok a gyermekjóléti szolgáltatások tárházában. Rubeus Egyesület. http://rubeus.hu/wpcontent/uploads/2018/10/szuloi_kompetenciafejlesztes_rubeus_20180919.pdf

Rácz, A. (szerk.) (2019). Bünelkövetéssel érintett gyermekeket és szüleiket támogató modellprogramok a gyermekvédelemben. Rubeus Egyesület. http://rubeus.hu/wp-content/uploads/2019/09/konyv_szulomkomp_BM2_final_201906.pdf

Rácz, A. (szerk.) (2020). A szülöség támogatásának új útjai a gyermekvédelemben. Rubeus Egyesület. http://rubeus.hu/wpcontent/uploads/2020/10/Rubeus_CSALADTAMOGATAS_UJ_UTJAI_2020_FINAL_KON YV_20201008.pdf

Sik, D. (2020). Prevenciós szemlélet a magyar gyermekvédelemben. Esély, 31(3), 94-111. http://www.esely.org/kiadvanyok/2020_3/94-111_sik_dorottya.pdf 